\title{
NOTE
}

\section{A reconnaissance oxygen isotope study of clinopyroxenes from four Japanese skarn deposits}

\author{
Hidehiko SHIMAZAKI ${ }^{1}$ and MinORU KUSAKABE ${ }^{2}$ \\ Geological Institute, Faculty of Science, University of Tokyo, Hongo, Tokyo $113^{1}$, and Institute \\ for Study of the Earth's Interior, Okayama University, Misasa, Tottori-ken, 682-02 ${ }^{2}$, Japan
}

(Received March 26, 1986: Accepted May 15, 1986)

\begin{abstract}
Oxygen isotopic compositions are determined for eleven clinopyroxenes from the Kamioka $(-2.4$ $\sim-0.4 \%$, SMOW), Tsumo $(+5.0 \sim+7.0)$, Yaguki $(-1.5 \sim+2.5)$ and Fujigatani $(+10.5 \sim+10.8)$ skarn deposits in Japan. Oxygen isotope values of ore-forming fluids estimated from the obtained data on clinopyroxenes are generally in good agreement with those estimated from the published data on skarn calcites. Among the studied deposits, the skarns in the Kamioka and Yaguki mines were formed under the influence of fluids with considerably low oxygen isotopic ratios.
\end{abstract}

\section{INTRODUCTION}

Many recent papers have demonstrated that stable isotope studies are powerful to trace fluid sources and fluid-rock interactions in a variety of geologic environments. Since classical works by Shieh and Taylor (1969) and by Taylor and O'Neil (1977), stable isotope investigations of skarn deposits also have realized satisfactory results in interpreting skarn petrogenesis (e.g., Bowman et al., 1985a, b; Brown et al., 1985; Rose et al., 1985).

According to these previous works, calcite crystals observed interstitially among skarn silicate minerals in deposits, called skarn calcite hereafter, have oxygen and carbon isotope values completely different from those of surrounding carbonate rocks, and in most cases have values defined by the fluids responsible for the formation of the skarn silicates. Morishita and Matsuhisa (1983) also recognized in a preliminary report on the Kamaishi Fe-Cu skarn deposits, that skarn calcites have rather constant oxygen and carbon isotope values, and are thought to have been precipitated in isotopic equilibrium with the solution and associated minerals such as magnetite and quartz in the deposits.

On the basis of these investigations, an attempt started to estimate oxygen and carbon isotopic compositions of hydrothermal solutions responsible for major skarn deposits in Japan, using the isotopic data on skarn calcites from those deposits (Shimazaki et al., 1985; Shimizu et al., 1986). It is, however, not fully confirmed yet whether skarn calcites always have isotopic compositions equilibrated with fluids of main ore-forming stages in each deposit. Thus, the purpose of the present work is to know, although very preliminarily, isotopic compositions of silicate oxygen in some representative skarn deposits in Japan, and to check whether the data are concordant with those obtained in the study on skarn calcites.

\section{EXPERIMENTAL}

In order to estimate oxygen isotopic compositions of ore-forming fluids, eleven clinopyroxene samples were provided from four skarn deposits in Japan. Clinopyroxene is a main constituent of skarns in most deposits, and is noticed as a reliable recorder of the oxygen isotopic compositions of fluids prevailed (Brown et al., 1985). Matthews et al. (1983) experimentally determined the temperature dependence of oxygen isotope fractionation factor between diopside and water, and recognized no 
Table 1. Oxygen isotopic composition of clinopyroxenes from Japanese skarn deposits

\begin{tabular}{|c|c|c|c|c|}
\hline Mine Name & Sample No. & $\begin{array}{c}\delta^{18} \mathrm{O}(\% \mathrm{o}) \\
\text { (SMOW) }\end{array}$ & Locality & Specimen \\
\hline \multirow[t]{3}{*}{ Kamioka } & HS73051011 & -0.4 & Tochibora Adit, $-300 \mathrm{~mL}$, No. 9 O.B. & Cpx sk with $\mathrm{Zn}-\mathrm{Pb}$ ore \\
\hline & HS83082704 & -0.7 & Tochibora Adit, $-240 \mathrm{~mL}$, Sasabira O.B. & Cpx sk with $\mathrm{Zn}-\mathrm{Pb}$ ore \\
\hline & HS65071402 & -2.4 & Maruyama Adit, $200 \mathrm{~mL}$, No. 1 O.B. & Cpx sk with $\mathrm{Zn}-\mathrm{Pb}$ ore \\
\hline \multirow[t]{3}{*}{ Tsumo } & HS75100306 & +5.0 & Maruyama Adit, $-225 \mathrm{~mL}$ & Cpx sk with W ore \\
\hline & HS71102504 & +7.0 & Maruyama Adit, $-75 \mathrm{~mL}$ & Cpx sk with $\mathrm{Cu}$ ore \\
\hline & HS62081101 & +6.1 & Maruyama Adit, $-25 \mathrm{~mL}$ & Gar-cpx sk with $\mathrm{Cu}-\mathrm{Zn}$ ore \\
\hline \multirow[t]{3}{*}{ Yaguki } & HS65081709 & +0.5 & No. 1 O.B., $130 \mathrm{~mL}$, W360 & Barren cpx sk \\
\hline & HS65080401 & +2.5 & No. 1 O.B., $250 \mathrm{~mL}$, W60N2 & Barren cpx sk \\
\hline & HS65111801 & -1.5 & No. 2 O.B., $360 \mathrm{~mL}$, W360 & Cpx sk with $\mathrm{Cu}-\mathrm{W}$ ore \\
\hline \multirow[t]{2}{*}{ Fujigatani } & HS72081603 & +10.8 & Akemidani Adit, $-100 \mathrm{~mL}$, No. 2 O.B. & Cpx-gar sk with W ore \\
\hline & HS72081620 & +10.5 & Akemidani Adit, $-20 \mathrm{~mL}$, No. 1 O.B. & Barren cpx-gar sk \\
\hline
\end{tabular}

Abbreviations - cpx: clinopyroxene, gar: garnet, L: mine level, O.B.: ore body, sk: skarn

significant difference in the fractionation data for diopside and hedenbergite.

Four skarn deposits were selected because each of them is a representative of different types of skarn deposits in Japan, that is, the Kamioka $\mathrm{Zn}-\mathrm{Pb}$, Tsumo $\mathrm{Cu}-\mathrm{Zn}-\mathrm{Pb}$, Yaguki $\mathrm{Cu}-$ Fe-W and Fujigatani W deposits. Geology and mineralization of these deposits are reported in many previous papers: e.g., Okuno (1964) and Akiyama (1980) on the Kamioka, Shimazaki (1968a, b) and Sugaki et al. (1981) on Tsumo, Shimazaki (1969) and Ogawa and Shida (1975) on Yaguki, and Sato (1980) and Matsueda and Arai (1982) on Fujigatani deposits.

The skarn specimens were crushed, and cleavage pieces of clinopyroxene were picked up under the binocular. Oxygen in the clinopyroxene samples was extracted by the $\mathrm{BrF}_{5}$ technique (Clayton and Mayeda, 1963). The pulverized samples of about $18 \mathrm{mg}$ each were placed in nickel reaction tubes, and were reacted with $\mathrm{BrF}_{5}$ at $600^{\circ} \mathrm{C}$ for 11 hours. The outline of the gas preparation line used in the present study was given by Matsuhisa et al. (1971). Oxygen isotope ratios of obtained $\mathrm{CO}_{2}$ gas were measured with a Nier-McKinney type mass spectrometer, and the results are given relative to the standard SMOW in terms of a conventional $\delta$ expression in per mil unit. The total uncertainty in $\delta^{18} \mathrm{O}$ values in the present measurements, is estimated to be $\pm 0.2 \%$ or better. Some samples were measured twice, and the results were identical within this error range.

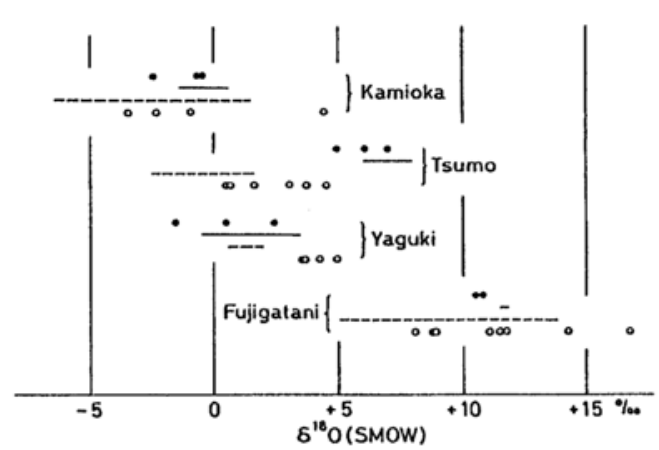

Fig. 1. Oxygen isotopic compositions of clinopyroxenes from four Japanese skarn deposits, with those of fluids estimated from the data on clinopyroxenes and skarn calcites. Solid circle represents clinopyroxene (this study), and open circle skarn calcite (Shimazaki et al., 1985; Shimizu et al., 1986). Bar and dash lines show the ranges of oxygen isotopic compositions of fluids estimated from clinopyroxene and skarn calcite, respectively.

\section{REsUlts AND Discussion}

Oxygen isotope data obtained are summarized in Table 1 with some comments on the occurrence of the specimens, and are plotted in Fig. 1 as solid circles. Although the whole range of isotopic values of clinopyroxenes is from -2.4 to $+10.8 \%$, those from the same mine show relatively small variation of 2 to $4 \%$, and seem to represent a range peculiar to each mining area.

As stated before, oxygen isotope data have been accumulated on skarn calcites from these 
deposits (Shimazaki et al., 1985; Shimizu et al., 1986). Figure 1 includes comparison of oxygen isotopic compositions of fluids estimated from the clinopyroxenes and skarn calcites. The fractionation between clinopyroxene and water is taken as $-1 \%$ (Matthews et al., 1983) on the assumption that the skarns were formed at about $500^{\circ} \mathrm{C}$. The fractionation between calcite and water is taken as 3\%o (O'Neil et al., 1969) on the assumption that the skarn calcites were precipitated at about $400^{\circ} \mathrm{C}$. Although no temperature estimation has yet been carried out on the studied clinopyroxene and calcite samples, approximate formation temperatures of $500^{\circ} \pm 50^{\circ} \mathrm{C}$ for anhydrous skarn silicate assemblages, and of $400^{\circ}-300^{\circ} \mathrm{C}$ for quartz-calcitehydrous mineral assemblages, are confirmed in various skarn deposits (e.g., Bowman et al., 1985b; Brown et al., 1985). The temperature dependence of oxygen isotope fractionation factor between clinopyroxene and water is so small that temperature estimation error, say $\pm 100^{\circ} \mathrm{C}$, gives almost negligible effect on the estimated $\delta^{18} \mathrm{O}$ values of fluids. The temperature dependence of fractionation factor between calcite and water is relatively large, especially in the lower temperature range. The fractionation between calcite and water is $5.5 \%$ at about $300^{\circ} \mathrm{C}$. If skarn calcites, however, were precipitated above $300^{\circ} \mathrm{C}$ it could be concluded that oxygen isotopic compositions of fluids are not much different for the skarn silicates and skarn calcite stages in each mine. The fact gives a sound base for estimating oxygen isotopic compositions of ore-forming fluids from the data on skarn calcites.

There is, however, an exception such as the Tsumo mine where about $5 \%$ discrepancy in fluid compositions was obtained between those estimated from clinopyroxene and calcite. The discrepancy could not be explained by uncertainty in the estimation of formation temperatures of two minerals. Oxygen isotopic composition of fluids was most likely lowered when the skarn calcite stage was reached. In the deposits, hydrothermal fluids of diverse origins are supposed to have contributed to the forma. tion and later modification of the ore deposits. Thus, oxygen isotopic compositions of fluids can be estimated from the isotopic data on skarn calcites, but an independent confirmation through analyses of skarn silicates is recommended.

Another remarkable feature shown in Fig. 1 is the prevalence of fluids with relatively low oxygen isotopic ratios for some deposits such as in the Kamioka and Yaguki mines. In fact, Wada (1978) has reported that $\delta^{19} \mathrm{O}$ values for calcites in the Kamioka deposits distribute in the range of several per mil around zero. The Kamioka is one of the most productive mines in Japan, and the origin of the deposits has long been debated with a large spectrum of interpretations from modified Precambrian syngenetic deposits (Akiyama, 1980) to skarn deposits genetically related to latest Cretaceous to early Tertiary felsic igneous activity (Okuno, 1964). The fact that fluids with low $\delta^{18} \mathrm{O}$ values prevailed not only at later stages but also at the skarn-forming stage, suggests continuous participation of meteoric water in the formation of the Kamioka deposits.

Acknowledgements-A part of this work was carried out under the Visiting Researcher's Program of the Institute for Study of the Earth's Interior, Okayama University. The authors are much indebted to Professor Hiroji Honma and Miss Masami Noto of Institute for Study of the Earth's Interior, Okayama University, for use of the oxygen extraction line and technical help in the experiments. Thanks are also due to Dr. Masaaki Shimizu of the University Museum, University of Tokyo, and Dr. Takanori Nakano of the Institute of Geoscience, the University of Tsukuba, for their keen interests in the present subject and critical discussion.

\section{REFERENCES}

Akiyama, S. (1980) Geological structure of the Hida metamorphic belt and mineralization of the Kamiokatype ore deposits - Studies on regional geology and mineralization in the Kamioka district, No. 1. Kozan Chishitsu 30, 345-362 (Japanese).

Bowman, J. R., O'Neil, J. R. and Essene, E. J. (1985a) Contact skarn formation at Elkhorn, Montana. II: Origin and evolution of C-O-H skarn fluids. Am. J. Sci. 285, 621-660. 
Bowman, J. R., Covert, J. J., Clark, A. H. and Mathieson, G. A. (1985b) The CanTung E zone scheelite skarn orebody, Tungsten, Northwest Territories: Oxygen, hydrogen, and carbon isotope studies. Econ. Geol. 80, 1872-1895.

Brown, P. E., Bowman, J. R. and Kelly, W. C. (1985) Petrologic and stable isotope constraints on the source and evolution of skarn-forming fluids at Pine Creek, California. Econ. Geol. 80, 72-95.

Clayton, R. N. and Mayeda, T. K. (1963) The use of bromine pentafluoride in the extraction of oxygen from oxides and silicates for isotopic analysis. Geochim. Cosmochim. Acta 27, 43-52.

Matsueda, H. and Arai, K. (1982) Vein skarn with ferrobustamite in the Mukai-hi Seibu ore body of the Fujigatani mine, Yamaguchi Prefecture. Kozan Chishitsu 32, 129-140 (Japanese).

Matsuhisa, Y., Matsubaya, O. and Sakai, H. (1971) $\mathrm{BrF}_{5}$-technique for the oxygen isotopic analysis of silicates and water. Shitsuryo Bunseki 19, 124 -133 (Japanese).

Matthews, A., Goldsmith, J. R. and Clayton, R. N. (1983) Oxygen isotope fractionations involving pyroxenes: The calibration of mineral-pair geothermometers. Geochim. Cosmochim. Acta 47, 631-644.

Morishita, Y. and Matsuhisa, Y. (1983) Carbon and oxygen isotope compositions of skarn minerals and related rocks in the Kamaishi mine. Abstr. Joint Meet. Soc. Mining Geol. Japan, Mineral. Soc. Japan, and Japan. Assoc. Mineral. Petrol. Econ. Geol. C-11 (Japanese).

Ogawa, K. and Shida, A. (1975) Scheelite mineralization in the Shin-bu tungsten deposit of the Yaguki mine. Kozan Chishitsu 25, 109-122 (Japanese).

Okuno, T. (1964) Skarns in the Kamioka mine. Papers Inst. Thermal Spring Res., Okayama Univ. 34, 63-94.

O’Neil, J. R., Clayton, R. N. and Mayeda, T. K. (1969) Oxygen isotope fractionation in divalent metal carbonates. J. Chem. Phys. 51, 5547-5558.

Rose, W. A., Herrick, D. C. and Deines, P. (1985) An oxygen and sulfur isotope study of skarn-type magnetite deposits of the Cornwall type, southeastern Pennsylvania. Econ. Geol. 80, 418-443.
Sato, K. (1980) Tungsten skarn deposit of the Fujigatani mine, Southwest Japan. Econ. Geol. 75, 1066-1082.

Shieh, Y. N. and Taylor, H. P., Jr. (1969) Oxygen and carbon isotope studies of contact metamorphism of carbonate rocks. J. Petrol. 10, 307-331.

Shimazaki, H. (1968a) Geology and ore deposits of the Tsumo mine, Shimane Prefecture. Japan. J. Geol. Geogr. 39, 55-71.

Shimazaki, H. (1968b) Genesis of pyrometasomatic ore deposits of the Tsumo mine, Shimane Prefecture. Japan. J. Geol. Geogr. 39, 73-87.

Shimazaki, H. (1969) Pyrometasomatic copper and iron ore deposits of the Yaguki mine, Fukushima Prefecture, Japan. J. Fac. Sci., Univ. Tokyo, Sec. II 17, 317-350.

Shimazaki, H., Shimizu, M. and Nakano, T. (1985) Oxygen and carbon isotopic compositions of oreforming fluids responsible for major skarn deposits in Japan, estimated from the data on carbonates. Abstr. Joint Meet. Soc. Mining Geol. Japan, Mineral. Soc. Japan, and Japan. Assoc. Mineral. Petrol. Econ. Geol. C-15 (Japanese).

Shimizu, M., Shimazaki, H. and Nakano, T. (1986) Characteristics of oxygen and carbon isotopic compositions of ore-forming fluids responsible for major skarn deposits in Japan (abstr.). Kozan Chishitsu 36, 54 (Japanese).

Sugaki, A., Soeda, A., Shima, H., Kitakaze, A., Hirowatari, F., Mariko, T. and Takeno, S. (1981) Ore deposits and minerals of the pyrometasomatic deposit of the Tsumo mine, with special reference to Maruyama deposit. Kozan Chishitsu Spec. Issue 9, 89-144 (Japanese).

Taylor, B. E. and O'Neil, J. R. (1977) Stable isotope studies of metasomatic $\mathrm{Ca}-\mathrm{Fe}-\mathrm{Al}-\mathrm{Si}$ skarns and associated metamorphic and igneous rocks, Osgood Mountains, Nevada. Contrib. Mineral. Petrol. 63, 1-49.

Wada, H. (1978) Carbon isotopic study on graphite and carbonate in the Kamioka mining district, Gifu Prefecture, central Japan, in relation to the role of graphite in the pyrometasomatic ore deposition. Mineral. Deposita 13, 201-220. 